Royal Navy in 1943-44, and since 1950 they have formed part of the Falkland Islands Dependencies Survey Meteorological Service, which has its headquarters at Port Stanley and performs all the usual functions of a meteorological service, including weather forecasting. The book, which was prepared in the Climatological Division of the Meteorological Office, is in three parts : a general discussion, written by Dr. J. Pepper; a gazetteer of stations; and climatic tables.

The publications of the meteorological work on Antarctic expeditions include some of the classics of meteorology but, on the whole, they are restricted in time and space. This is the first publication to survey the weather of a large area of the Antarctic for so long a period. The weather of the area is controlled by the continual passage of depressions and the intervening ridges of high pressure; and so it is very changeable, with relatively small seasonal variations but large changes associated with the passage of fronts. Mean pressure is low-about $900 \mathrm{mb}$. at the Dependencies and 1,000 mb. at the Fallklands. Mean monthly temperature varies between about $35^{\circ} \mathrm{F}$. in summer and $15^{\circ} \mathrm{F}$. in winter over the Dependencies, and $48^{\circ} \mathrm{F}$. in summer and $35^{\circ} \mathrm{F}$. in winter at the Falklands. Rises and falls of temperature of up to $40 \mathrm{deg}$. F. occur in the Dependencies with the passage of warm and cold fronts respectively. An interesting comparison with northern-hemisphere stations at the similar latitudes and situations (for example, Godthaab in Greenland) shows the Antarctic ones to have warmer winters and cooler summers, demonstrating the more intense circulation of the Antarctic. Interesting details are the very high frequency of visibility exceeding $4.0 \mathrm{~km}$. and the 'burning' of sunshine cards at solar elevations less than $2^{\circ}$-exomplifying the purity of the air-the observation of iridescent clouds by moonlight, and the exactness with which the rise of temperature in air descending from the 5,000 $\mathrm{ft}$. plateau to Marguerite Bay corresponds to the adiabatic value.

The tables include monthly summaries of all the meteorological elements, and frequency tables for many of them for all the stations. Special praise must be given to the gazetteer, with its photographs and detailed topographical descriptions. It is regrettable that no index is provided.

\section{OPTIMAL SPAN OF WORKING LIFE}

Ageing in Industry

An Inquiry based on Figures derived from Census Reports into the Problems of Ageing under the Conditions of Modern Industry. By F. Le Gros Clark and Agnes C. Dunne. Pp. xi +149 . (London : The Nuffield Foundation, 1955.) 6s.

\footnotetext{
THE only people who seem to have solved the problem of their senescent members seem to have been the mythical Hyperboreans whose aged, when they wished to retire from life, performed a "joyful suicide" by decking themselves with garlands and precipitating themselves from a rock into the sea. Non-mythical peoples have found various other solutions. The Tibarini used to hang their old on gibbets, the Hircanians and Bactrians cast them, while still living, to the dogs, and the Scythians buried them alive.
}

In Great Britain such drastic measures have never been contemplated, although the plight of the aged has often given cause for much distress. During the past two or three decades we have become increasingly conscious of the wider repercussions of our ageing population and the resulting social and economic disadvantages. The highly complex situation was fully examined by the Royal Commission on Population (1949). The Commission's report was particularly concerned with the growing 'burden of dependency', that is, the decline in the proportion of producers per consumer, and it emphasized the desirability of prolonging the productive capacity of workers beyond the age of sixty-five. At that time, however, it was not possible to give anything like a precise answer to tho question: "At what ages are men compelled, by reason of their age alone, to leave the occupations in which they have spent their working lives ?" This is the important question to which Mr. F. Le Gros Clark and Miss Agnes Dunne address themselves in this book. Their inquiry is based on figures derived from the Census Reports for 1921, 1931 and 1951 and relates to four million men in thirty-two occupations, representing about a quarter of the occupied male population of Britain in 1951. The principal method of analysis employed by them is that of the 'moving cohort'; they have taken a decennial age-group from each of the thirty-two occupations at 1921 and followed it through until 1951 .

They define the 'survival-rate' of working men as the proportion of men who reach their mid-sixties in a given job and are physically capable of remaining in it until their late sixties or beyond. The survivalrates for the different occupations range from 75-85 per cent among watch-and clock-makers to .5-15 per cent among workers at the coal face. Agricultural workers and men in certain building trades have relatively high survival-rates as compared, for example, with tobacco workers, compositors, foundrymen, bus conductors and constructional engineers. By appropriately weighting the thirty-two occupations and making allowance for the proportion who would have to cease work because of impaired health, the investigators estimate that alternative jobs would have to be found for $20-30$ per cent of those aged 55-64 in 1951. For the country as a whole, this amounts to forty thousand alternative jobs to be found every year over the relevant ten years.

A second analysis shows the ratio of those aged 65 and over to those aged 35-64 in each of the thirty. two occupations. This reveals considerable variation between the occupations in respect of their employment of older men, a variation which suggests an incapacity on the part of many workers to remsin in certain occupations under present conditions. In a third analysis the investigators show the changes in age structure of the occupations which took place between 1931 and 1951 in relation to the contraction or expansion of the occupation.

This is a most valuable study which will provide industry, the trade unions and many government departments with much-needed food for thought and perhaps a first guide to action. The authors' efforts will not have been in vain if their report leads at least to serious research into possible alternative jobs for older people and into methods of reducing the stresses which make them leave their work at an age earlier than they might otherwise do. The Nuffield Foundation has rendered another public service in sponsoring this report.
JoHN COHEN 